\title{
Albert Wendt: Bibliography
}

\section{Paul Sharrad and Karen M Peacock, compilers}

\begin{abstract}
We endt is clearly a leading figure in literary creativity and cultural criticism in the Pacific region. He is only beginning, however, to get the kind of international attention that equivalent figures from other regions have received. Apart from an honorary doctorate from the University of Bourgogne, recognition of his work has been largely confined to occasional journal articles and general studies of Pacific literatures. There is now, however, a PhD devoted solely to his work and quite a large body of critical material. In order to encourage future studies of this important and complex writer, this listing is offered as the most complete reference guide to date. It is not entirely complete, since some details from clippings have defied attempts at verification, but it is comprehensive, and we trust, useful to others. This work was originally created by Paul Sharrad, and updated by Karen Peacock in January 2003. Readers finding extra information are invited to contact the principal compiler so that an updated list can be established on the Internet: Paul Sharrad, School of English Literatures, Philosophy, and Language, University of Wollongong, Northfields Avenue, Wollongong NSW 2522, Australia; fax +6I-2-2I447I; email $<$ paul_sharrad@uow.edu.au $>$.

Thanks for help with bibliographic searches go to Michelle Keown; Ray Riach and the staff of the New Zealand/Pacific Collection at the University of Waikato; staff of the New Zealand \& Pacific Collection, University of Auckland Library; Mrs Mereani Vakasisikala of the Pacific Collection at the University of the South Pacific (USP) Library; Robin Griffin, archivist at the Auckland College of Education; staff of the University of Wollongong Library; and the staff of Pacific Collection, Hamilton Library, University of Hawai'i, Mānoa (UHM); and to Jan Rensel, editor at the
\end{abstract}

The Contemporary Pacific, Volume I5, Number 2, Fall 2003, 378-420

(C) 2003 by University of Hawai'i Press 
UHM Center for Pacific Islands Studies, for attention to detail. Grateful acknowledgment for travel support is made to the University of Wollongong and the Australian Academy of the Humanities. Thanks to Kimberley Haines of uнм Hamilton Library for proofreading of citations.

This bibliography lists, first, writings by Wendt himself: literary works (poems, stories, plays, novels, collections, edited volumes, translated books); films based on his literary works; television documentaries about him; sound recordings of his poetry; and his essays. There are individual entries for poems and stories first published in Wendt's own collections if they were reprinted elsewhere. Information about items published in more than one place in the same year is noted after the phrase "also published." Works are listed in order of first publication located.

In this bibliography, Wendt's works are followed by interviews with or profiles of Wendt, then reviews or articles on specific works, starting with a review of his plays, then of specific works in order of publication. Next are studies focusing on Wendt and his work, followed by general studies, and finally, bibliographical sources.

Table I. Wendt Publications Codes

\begin{tabular}{llll}
\hline Title & Type & Year & Code \\
\hline Sons for the Return Home & novel & 1973 & SR \\
Flying-Fox in the Freedom Tree & stories & 1974 & $F F$ \\
Some Modern Poetry from Western Samoa & anthology & 1975 & $S M$ \\
Inside us the Dead & poems & 1976 & $I D$ \\
Pouliuli & novella & 1977 & $P$ \\
Leaves of the Banyan Tree & novel & 1979 & LB \\
Lali & anthology & 1980 & $L$ \\
Shaman of Visions & poems & 1984 & SV \\
Birth and Death of the Miracle Man & stories & 1986 & $B D M$ \\
Ola & novel & 1991 & $O$ \\
Black Rainbow & novel & 1992 & $B R$ \\
Nuanua & anthology & 1995 & NN \\
Photographs & poems & 1995 & $P H$ \\
The Best of Albert Wendt's Stories & stories & 1999 & $B E S T$ \\
The Book of the Black Star & art, poems & 2002 & $B B S$ \\
Whetu Moana & anthology & 2003 & WM \\
\hline
\end{tabular}




\section{LITERARY WORKS BY WENDT}

I959a The Beauty of the Night [poem]. Farrago 1959 Annual Magazine of the Ardmore Teachers' College Students' Association, Auckland: 7. (Auckland College of Education Archives: ARTC: в 5.)

I959b Uncle [short story]. Farrago I959 Annual Magazine of the Ardmore Teachers' College Students' Association, Auckland: 26-28. (Auckland College of Education Archives: ARTC: B 5.)

r96ra The Bayonet; A Second Christ [stories]. Experiment (Wellington) 8:60-7I.

I96Ib Fishing [children's story]. New Zealand School Journal part 4, Summer.

I962a Alo and Seve; How Nuufaanoanoa became Nuufiafia; The Children and the Pigs [children's stories]. New Zealand School Journal part 3, Winter.

I962b Now Chained; Death of the Sun [poems]. Argot (Wellington) I (4): unpaginated.

I962c Virgin-Wise: The Last Confession of Humble Man Who is Man Got Religion [story]; Argot I (4): unpaginated. (Rp FF, I45-I48; BEST, I3I-I33.)

I963a The Apple Tree. Mate (Auckland literary magazine).

I963b A Descendant of the Mountain [story]. Landfall (Christchurch, NZ) I7 (I): II 3-I I 8. (Rp I973 in My New Zealand Senior. Auckland: Longman Paul; FF, I-6; 1989 in Pacific Voices: An Anthology of Maori and Pacific Writing, edited by Bernard Gadd, 46-48. Auckland: Macmillan New Zealand; BEST, 7-II)

I963c I, God Uphere [poem]. New Zealand Universities Arts Festival Yearbook, 6. Wellington: NZU Publications. (Rp ID, I; I997 Bornholdt and others, I07.)

I963d The Name of the Game [story]. Landfall I7 (4): 328-332.

r963e Put on your Mask of Manhood [poem]; Tagata, the Man Who Search for the Freedom Tree [story]. New Zealand Universities Arts Festival Yearbook, 7, 24-29. Wellington: NZU Publications.

I964 The Dark Angel [story]. New Zealand Listener, 3 July: 5, 2I. (Rp 1973 in Short Stories by New Zealanders, edited by Phoebe Meikle, II2-I2I. Auckland: Longman Paul; 1977 in New Zealand Listener Short Stories, edited by Bill Manhire, 69-76. Wellington: Methuen. 1982 translated into Chinese in Oceanic Literature $\mathrm{I}: 202-2 \mathrm{I} 2$.) 
I965a Colonialism, Independence [poem]. Te Maori (Wellington). (Rp ID, 20; 1977 in Pacific Voices: An Anthology of Writing By and About Pacific People, edited by Bernard Gadd, 70. Albany: Stockton House; 1997 Bornholdt and others, I09.)

I965b Moon Marriage [poem]. Te Maori. (Rp 1973 Illustrated Weekly of India, 2 Dec: 35; I974 in McQueen and Cox, I78; ID, I9.)

I967a The Pastor [poem]. New Zealand Listener, 7 July, 20. (Rp ID, I6.) I967b Rebel [poem]. New Zealand Listener, 3 Nov, 6.

I967c Stranger on the Plateau [poem]. New Zealand Listener, I4 July, I9. (Rp 1973 Illustrated Weekly of India, 2 Dec, 35; ID, 5-6.)

I968 The Shell I live in [poem]. New Zealand Listener, 5 Jan, 4. I969a For Sina [poem]. Landfall 23 (2): I I8. (Rp I974 McQueen and Cox, I77; ID, 2I.)

I969b Lava Field and Road, Savaii [poem]. Landfall 23 (2): I I6-II7. (Rp 1974 McQueen and Cox, I79; ID, 23-24.)

I969c Panthers [poem]. Landfall 23 (2): i I 8, (Rp I97 I Poet [London] March: I-2; I973 Illustrated Weekly of India, 2 Dec, 35; I974 McQueen and Cox, I76; ID, I7.)

I970a Conch Shell [poem]. Landfall 24 (4): 338. (Rp I974 McQueen and Cox, I84; ID, 32-33; L, 29I-292; I990 Pacific Islands Voices: A Literary Newsletter (Honolulu) 2 [Summer]: 3.)

I970b Conversation [poem]. Landfall 24 (4): 340. (Rp 1974 McQueen and Cox, $176 ; I D, 28$.

I970c Flying-Fox [poem]. Landfall 24 (4):339. (Rp I974 McQueen and Cox, I 80; ID, 26; I979 Mishra, I 5.)

I970d He Never Once Lost His Way [poem]. Landfall 24 (4): 340-34I. (Rp 1974 McQueen and Cox, I85; ID, 29.)

I970e Hop Bird [poem]. Landfall 24 (4):339. (Rp I974 McQueen and Cox, I8I.)

I970f Inside us the Dead (Prologue; I Polynesians; 2 Missionaries; 3 Traders; 4 Maternal myth; 5 The ball thrown up) [poem]. Landfall 24 (3): 219-226. (Rp ID, 7-I4; L, 284-290; 2000 in Remembrance of Pacific Pasts: An Invitation to Remake History, edited by Robert Borofsky, 35-42. Honolulu: University of Hawai'i Press.)

I970g Love in a Winter City [poem]. Landfall 24 (4): 337. (Rp I973 Illustrated Weekly of India, 2 Dec, 35; ID, 30.)

I970h Poets \& Poems for the Seventies [poems by Wendt and seven other poets]. Landfall 24 (4):337-34 I. [Includes Love in a Winter City; 
Conch Shell; Flying-Fox; Hop Bird; Conversation; He Never Once Lost His Way.]

I97 Ia Nazis? What is Nazis? [story]. Landfall 25 (4): 409-4I3. (Rp as chapter 8 in SR; 1973 in My New Zealand Senior.)

I97Ib Polynesians [poem]. Detroit: Broadside Press.

I972a Comes the Revolution. Unpublished play performed at the First South Pacific Arts Festival, Suva, Fiji, 6-20 May.

I972b The Contract. Unpublished play performed at the Schools' Drama Festival, Apia, Samoa.

I972 C My Uncle, the Consumptive, or, How to Cultivate the Worms and Live a Long Happy Life. Landfall 26 (I): 59-6I. (Rp 1974 McQueen and Cox, I86-I87; ID, 34-35).

I972d Vietnam. Niu (Yearbook of the Students' Association of the University of the South Pacific, North Melbourne, Victoria, Australia): 25.

I973a A Comic Love Song [poem]. Translated from Samoan. Mana Annual of Creative Writing r:85. Sydney: Pacific Publications. (Also published in Mana section, Pacific Islands Monthly 44 [го]: 63. Rp I976 Risk I2 [I]: 44.)

I973b A Fat Poem Thinning [poem]. Samoa College Magazine (Apia).

1973c From Lack of Oxygen [poem]. Mana Annual of Creative Writing: 89. (Also published in Mana section, Pacific Islands Monthly 44 [Io]: 67. Rp SM, 25.)

I973d In Memory of Jim Baxter [poem]. Mana Annual of Creative Writing: 89. (Also published in Mana section, Pacific Islands Monthly 44 [10]: 67.)

I973e Legislation [poem]. Mana Annual of Creative Writing: 89. (Also published in Mana section, Pacific Islands Monthly 44 [10]: 67; Illustrated Weekly of India, 2 Dec, 35; SM, 23.)

I973f Master Future [poem]. Illustrated Weekly of India, 2 Dec, 35. (Rp ID, I 5.)

I973g Me, Adam [poem]. Illustrated Weekly of India, 2 Dec, 35. (Rp McQueen and Cox, I77.)

I973h Months of it [poem]. Mana Annual of Creative Writing: I I. (Also published in Pacific Islands Monthly 44 [3]: 7I. Rp ID, 36-37.)

I973i Nightmare to Waking [poem]. Samoa College Magazine (Apia). (Rp ID, 3I.)

I973j Nine Pictures. Illustrated Weekly of India, 2 Dec, 35. (Rp I974 as Pictures in SM, 26-27; shorter version as Pictures in ID, 40.) 
I973k Poems by Albert Wendt. Illustrated Weekly of India (Bombay), 2 Dec, 35. [Includes Me, Adam; Love in a Winter City; Panthers; Master Future; Moon Marriage; Weather Forecast; Legislation; Nine Pictures; Sleep; Tamarind; Stranger on the Plateau.]

I9731 Random Thoughts [poem]. Mana Annual of Creative Writing: 89. (Also published in Mana section, Pacific Islands Monthly 44 [го]: 67.)

I973 $\mathrm{m}$ Songs and Poems for Children. Translated from Samoan. Mana Annual of Creative Writing: 84. (Also published in Mana section, Pacific Islands Monthly 44 [10]: 62.)

I973n Sons for the Return Home. Auckland: Longman Paul. (Rp I987 New York: Penguin; 1996 Honolulu: University of Hawai'i Press, Talanoa Series.)

I9730 To My Son, On the Tenth Anniversary of our Country's Independence [poem]. Mana Annual of Creative Writing: 22. (Rp ID, 38-39; I980 Pacific Islands Monthly 5 I [8]: I40.)

I973p Weather Forecast [poem]. Mana Annual of Creative Writing: 89. (Also published in Mana section, Pacific Islands Monthly 44 [Io]: 67; Illustrated Weekly of India, 2 Dec, 35. Rp SM, 28.)

I974a Albert Wendt [poetry]. In Ten Modern New Zealand Poets, edited by Harvey McQueen and Lois Cox, I72-187. Auckland: Longman Paul. [Includes Bulldozers in the Suburbs; Conch Shell; Conversation; Exam Time, New Zealand; The Fall; Flying-Fox; For Sina; He Never Once Lost His Way; Hop Bird; House; Lava Field and Road, Savaii; Me, Adam; Moon Marriage; My Uncle the Consumptive; Panthers; Town and Village; Words.]

I974b Captain Full: The Strongest Man Alive who got Allthing Strong Men got [story]. Thursday (Auckland), I9 Sept: 54-56, 59-60, 62. ( $\mathrm{Rp} F F, 2 \mathrm{I}-33$.)

I974C The Coming of the Whiteman [story]. Thursday, 26 Sept: 54-56, 59-60. (Rp FF, 72-83.)

r974d Exam Time, New Zealand [poem]. In McQueen and Cox, I74. (Rp ID, 4; I979 Mishra, I69.)

I974e The Fall [poem]. In McQueen and Cox, I 82. (Rp ID, 4I-42.)

I974f Flying-Fox in a Freedom Tree. Auckland: Longman Paul. (Rp I988 Auckland, New York: Penguin.)

I974g House [poem]. In McQueen and Cox, I83. (Rp ID, 27.)

I974 h No Islands in the Sun, Just Misters [poem]. In SM, 2I. (Rp ID, 5I; 1977 in Richness and Diversity: An English Language Book for 
Form 6, edited by Cliff Benson, 38. Suva: Institute of Education, University of the South Pacific; I979 Mishra, I4; I983 Hamasaki, 70; 1995 in Reef, Palm and Star: Poetry from the Nations of the Pacific, edited by Mike Horsley, 7. Sydney: St Clair Press.)

I974i Raiwaqa, Suva [poem]. In SM, 22. (Rp ID, 50; I979 Mishra, I4.) I974j A Resurrection. In FF, 65-7I. (Rp I996 in The Arnold Anthology of Post-Colonial Literatures in English, edited by John Thieme, 636-640. London: Arnold.)

I974k (ed.) Some Modern Poetry from Fiji. Suva: Mana Publications.

I974l (ed) Some Modern Poetry from Western Samoa. Suva: Mana Publications. [Includes his poems: This Morning; No Islands in the Sun, Just Misters; Raiwaqa, Suva; Legislation; Be-tween Us; What You Do Now, Brother; From Lack of Oxygen; Pictures; Weather Forecast.]

I974m A Talent [story]. Landfall 28 (4): 275-290. (Rp BDM, I I-30.)

I974n This Morning [poem]. SM, 20. (Rp ID, 52.)

I9740 Town and Village [poem]. In McQueen and Cox, I75. (Rp ID, I8; I997 Bornholdt and others, I08.)

I974p What You Do Now, Brother? [poem]. In SM, 24-25. (Rp ID, 48-49; I983 in Hamasaki, 68; I990 Pacific Islands Voices: A Literary Newsletter 2 [Summer]: 5.)

1975a (ed) Some Modern Poetry from the New Hebrides. Suva: Mana Publications. (Rp I983 as Some Modern Poetry from Vanuatu. Suva: Mana Publications.)

I975b (ed) Some Modern Poetry from the Solomons. Suva: Mana Publications.

I976a Birthday, Laucala Bay, Fiji [poem]. Mana Review (Suva) I (2): 26. (Rp SV, 4.)

I976b The Burden [story (part of Pouliuli)]. Islands I 5 ( I [Sept]): 9-I 5. 1976c Inside Us the Dead: Poems 196I-1974. Auckland: Longman Paul. (Rp I980).

I976d Lefaga [poem]. ID, 25. (Rp I978 Moana [Apia, published by the Western Samoa Writers Association with the UsP Centre] I [2]: Iо.)

I977a Birth and Death of the Miracle Man [story]. Hemisphere (Australia) 2I (8): I7-I9. (Rp I98I in Only Connect: Literary Perspectives East and West, edited by Guy Amirthanayagam and Syd Harrex, 259-264. Adelaide: Centre for Research in the New Literatures in English (CRNLE), and Honolulu: East-West Center; BDM, 35-43; broadcast on $\mathrm{NZBC}$ radio [nd].) 
I977b Exam Failure Praying [story]. Education (Wellington) 26 (2): 23. (Rp BDM, 54-55; 2000 in Small Packages, edited by Linda Burgess and Raewyn Bright, 68-70. Auckland: Longman.)

I977c The Fuluasou River, Upolu; We Had a Dog Once [poems]. Mana Review 2 (I): 47-48. (Rp L, 293, 294; SV, 5, 6.)

I977d Pouliuli. Auckland: Longman Paul. (Rp I980 Honolulu: University of Hawai'i Press; 1987 Auckland: Penguin Books.)

I978a O‘u Vae [poem]. Moana I (2): 9-го.

I978b Talanoaga [poem]. Moana I (2): Io.

I979a [Four poems.] In Waves: An Anthology, edited by Vijay Mishra, I 4-I 5, I 69. [Includes No Islands in the Sun, Just Misters; FlyingFox; Raiwaqa, Suva; Exam Time.]

I979b In the Midnight Ocean of His Sleep. Islands 26 (Torbay, NZ) 7 (4): 37 I-372. (Rp SV, 7.)

I979c Leaves of the Banyan Tree. Auckland: Longman Paul. (Rp I980 London: Allen Lane; 198I Harmondsworth: Penguin Books; 1984 as The Banyan, New York: Doubleday; 1987 London, New York: Penguin Books; and 1994 Honolulu: University of Hawai'i Press, Talanoa Series. 1982 translated into German by Doris Pfaff: Der Clan von Samoa: Roman aus West-Samoa. Wuppertal: Peter Hammer Verlag.)

I979d Three Poems for Kenzaburo Oe (The Barber's Chair; Oe, You; Your Son). Islands 267 (4):373-374. (Rp SV, IO-II; I994 in Boundary 2 2I (I), edited by Rob Wilson and Arif Dirlik, I63. Durham, NC: Duke University Press.)

I980a (ed) Lali: A Pacific Anthology. Auckland: Longman Paul.

I980b O Lenei Taeao [poem]. Moana 2 (I): 7.

I98I a The Balloonfish and the Armadillo [story]. The Bulletin (Sydney), Literary Supplement, 22-29 Dec: I 84-190. (Rp BDM, 56-72.)

I98Ib Elena's Son [story]. Mana: A South Pacific Journal of Language and Literature 6 (I): 49-57. (Rp BDM, 44-53.)

I98I Ic Mr. Knightly at Sixty-nine [poem]. Landfall 35 (3): 328.

I98Id Prospecting [story]. Echos $d u$ Commonwealth (Mont-St-Aignan, France) 8:5-26. (Rp BDM, 73-95.)

I98Ie The Season of the Moon; Traveller [poems]. Landfall 35 (I): 28-29. ( $\mathrm{Rp} S V$, I 2-I3.)

I982a Around Me the Night is Curling; A Souvenir [poems]. Mana 7 (2): 3, 5. ( $\operatorname{Rp} S V$, 19, 44.)

I982b Birthdays [story]. Landfall 36 (I): I I-I6. (Rp BDM, I26-I33.) 
I982 C House of the Spirit [poem]. Mana 7 (2): 4 .

I984a Daughter of the Mango Season [story]. Landfall 38 (I): 5-2 I. (Rp BDM, I34-I 54.)

I984b I Will be Our Saviour from the Bad Smell [story]. Islands I (I [July]): 34-54. (Rp I986 in Science Fiction and Fantasy Stories, edited by Bernard Gadd, Auckland: Longman Paul; BDM, 96-I 25, NN, 302-32I.)

I984c Knife [poem]. In $S V$, 57. (Rp NN, 322-323.)

I984d My Mother Dances [poem]. In SV, 26. (Rp I997 Bornholdt and others, I Iо.)

I984e No Return [poem]. In SV, 9. (Rp 1997 Bornholdt and others, I09.)

I984f Parents \& Children [poem]. In SV, 27. (Rp 1992 Honolulu Star Bulletin Io Feb: BI; NN, 322.)

I984g Shaman of Visions [poems]. Auckland: Auckland University Press and Oxford University Press.

I984h Shaman of Visions [poem]. In SV, 59. (Rp NN, 324.)

I984i Short Songs (hands; night; parrot fish) [poems]. In SV, I8. (Rp I997 Bornholdt and others, I09.)

I985 Hamlet [story]. Islands 2 (2 [Nov]): Ioo-Ii6. (Rp BDM, I64-I76.)

I986a The Birth and Death of the Miracle Man, and Other Stories. Auckland: Viking. (Rp I987 Harmondsworth: Penguin Books; I999 Honolulu: University of Hawai'i Press.)

I986b The Contest [poem (part of The Chronicles of Vela, a work in progress, unpublished to date)]. Landfall 40 (2): I44-I53. (Rp PH, 19-27.)

I986c Crocodile. In BDM, I 55-163. (Rp 1992 in The Oxford Book of New Zealand Short Stories, edited by Vincent O'Sullivan, 297303. Auckland: Oxford University Press.)

I986c The Mountains of Ta'u [poem]. Rambling Jack 3 (Nov): I9. (Rp PH, I7-I 8; I997 Bornholdt and others, I IO.)

I988a Monopoly [story (extract from BR)]. Landfall 42 (4): 363-374.

I988b No History/Herstory [story (extract from BR)]. Metro 8 (79): I $50-153$.

1988c (translator) Tuna o le Kapisivai ma Tamaiti o Champion Street by Patricia Grace, illustrated by Robyn Kahukiwa. Auckland: Puffin Books.

I989a Nightflight [sequence of 2 I poems]. Sport (Wellington) 3 (Spring), 
section 2I: I49-I66. (Rp The Wall [poem 2I in sequence] $N N$, 324-327.)

I989b Trollkarlens födelse och död. [Swedish extract from Leaves, translated by Kerstin Gustafsson]. Dagens Nyheter (Stockholm) I 5 (Jan): 7, 43 .

I99ra A Genealogy of Women [story]. In Soho Square IV, edited by Bill Manhire, 24-37. Compiled by Bloomsbury Publishing Ltd (London). Wellington: Bridget Williams Books. (Rp I993 Other Voices 3, edited by Bernard Gadd, I44-I 58. Auckland: Brick Row-Hallard; BEST, 264-268.)

I99Ib Ola. Auckland: Penguin Books. (Rp I995 Honolulu: University of Hawai'i Press.)

I992a Black Rainbow. Auckland: Penguin Books. (Rp I995 Honolulu: University of Hawai'i Press.)

I992b The Don'ts of Whistling [story (sequel to $B R$; section of $P H)$ ] Landfall 46 (4): 398-420. (Rp BEST, 279-30I.)

I993 Pages from Albert Wendt's Photograph Album [sections of $P H$ ]. Commonwealth Essays and Studies (University of Bourgogne, Dijon, France) I6 (2): I-6.

I994a In Your Enigma [poem]. Landfall ns 2 (I): 26. (Rp NN, 327-328; PH, 6.)

1994b Truth of Our Love [story]. In Tart and Juicy: Food Stories from Australian and New Zealand Writers, edited by Michael Gifkins, I 56-I64. Auckland: Vintage.

1995a (ed) Nuanua: Pacific Writing in English Since 1980. Auckland: Auckland University Press. (Also published Honolulu: University of Hawai'i Press, Talanoa Series.)

I995b Photographs. Auckland: Auckland University Press. [Includes some (unspecified) poems published previously in Soho Square, Malahat Review, Rambling Jack, Printout, and Sport.]

I997a [Seven poems.] In An Anthology of New Zealand Poetry in English, edited by Jenny Bornholdt, Gregory O'Brien, and Mark Williams, I07-III. Auckland: Oxford University Press. [Includes I, God Uphere; Town and Village; Colonialism: Independence; Short Songs (hands; night; parrot fish); No Return; My Mother Dances; The Mountains of $\mathrm{Ta}^{\mathrm{a}} \mathrm{u}$.]

I997b Three Poems (Treasure; Avana, Rarotonga; For Kauraka). Wasafiri (London) 25 (Spring): 34 .

I998 The eyes have it [story]. Southerly (Sydney) 58:4, 55-68. (Rp 
BEST; 200I in Authors' Choice: Leading New Zealand Writers Choose Their Best Stories-And Explain Why, edited by Owen Marshall. Auckland: Penguin Books.)

I999 The Best of Albert Wendt's Short Stories. Auckland: Random House New Zealand.

2000 The Bird [story]. Manoa: A Pacific Journal of International Writing 2I (I): 23O-24I.

2002 Book of the Black Star [poems]. Auckland: Auckland University Press.

2002 Robocop in Long Bay [story]. Landfall nsio (I): 76-90.

2003 (ed with Reina Whaitiri and Robert Sullivan) Whetu Moana: Contemporary Polynesian Poems in English [anthology]. Auckland: Auckland University Press.

FILMS

1979 Sons for the Return Home. I I7 minutes, vHs, color. Director: Paul Maunder; producer: Don Blakeney. Wellington: New Zealand Film Commission.

I989 Flying-Fox in a Freedom Tree. 90 minutes, vHs, color. Director, screenwriter: Martyn Sanderson; producer: Grahame McLean. Wellington: New Zealand Film Commission.

\section{DOCUMENTARIES}

I979 Angry Young Man of the Pacific with a Warning. 8 o'clock (New Zealand television series), 20 Oct. Producer: Graeme Kennedy.

I98I Albert Wendt: A Modern Tusitala. NZTV-I Landmark series. Producer: George Andrews.

I983 Pacific Writers Workshop. I80 minutes, vHs, B \& W. Suva: Institute of Education, University of the South Pacific. [Albert Wendt, Konai Helu Thaman, and other Pacific writers discuss the intricacies of their craft and read excerpts of their writings.]

I985 Auckland Fa'a Samoa. NZTV-I Lookout series.

I986 Panel Discussion on Biculturalism at Writers and Readers Week, New Zealand International Festival of the Arts: NZBC, 23 Sept, 9 PM.

I993 A Conversation with Albert Wendt. 30 minutes, vHs, color. KHET Spectrum Hawai $i$ series, 29 Sept. [Albert Wendt and Vilsoni Hereniko discuss the complexities of Pacific literature and art.] 


\section{SOUND RECORDINGS}

I974 Albert Wendt [six poems]. On New Zealand Poets Read Their Work, set of 2 LPs/cassette tapes, collected and edited by Jan Kemp, Alan Smythe, and Jonathan Lamb, record I, side A. Auckland: Waiata Recordings.

I98x[?] Konai Thaman: poems; Albert Wendt: poems. Sound cassette. Suva: Institute of Education, University of the South Pacific.

I999 Seeing Voices: New Zealand Poets Reading. Compact disc. 73 minutes, 55 seconds. Includes booklet. Auckland: Auckland University Press; Atoll.

\section{ESSAYS BY WENDT}

I965a Guardians and Wards: A Study of the Origins, Causes, and First Two Years of the Mau in Western Samoa. MA thesis, Victoria University of Wellington.

I965b A Letter from Paradise. Kiwi '65 Auckland University Students' Association: 50-52.

I973 Ueta Solomon: Teacher, Musician, Composer [interview by Albert Wendt]. Pacific Islands Monthly 44 (I O): 65-66.

I974 Inside "Outsider" Wendt. New Zealand Bookworld (Wellington) 8 (Feb/March): 6-8.

I975 A Sermon on National Development, Education and the Rot in the South Pacific. In Education in Melanesia, edited by T Brammel, R May, and M Allen, 373-380. Canberra: Australian National University Press.

I976a The Angry Young Men of Oceania. UNESCO Courier (Feb): 4-I I, 32. ( $\mathrm{Rp}$ I980 as Die Aufständischen des Pazifiks, in Traüme von der Südsee, 98-I06. Göttingen: Missionschilfe Verlag/Vandenhoek \& Ruprecht.)

I976b How to Get Students Writing Poetry. Multicultural School (Auckland) $3: 15-18$.

I976c In a Castle in the South Seas. Mana Review I (2): 27-32. (Rp I977 in The Literary Half-Yearly [Mysore, India] I 8 [I]: I 52-I60.)

I976d Towards a New Oceania. Mana Review I (I): 49-60. (Rp I982 in Writers in East-West Encounter: New Cultural Bearings, edited by Guy Amirthanayagam, 202-2 I 5. London: Macmillan; 1983 in Hamasaki, 7 I-85; 1993 in Readings in Pacific Literature, edited by Paul Sharrad, 9-19. Wollongong: New Literatures Research Cen- 
tre; 1996 in The Arnold Anthology of Post-Colonial Literatures in English, edited by John Thieme, 64 I-65I. London: Arnold.)

I977a Albert Wendt on “Animal Farm.” Education 26 (3): 25.

I977b ["Comment" column in Samoa Times, writing as Pati Tuao]:

A One Year Old Government. 2I Jan.

Planning from Below and Rural Affluence as Cocktail Conversation Pieces. 4 March.

The Price of a Lucrative Export. I 8 March.

Politician and Laughter. I April.

Apia. 7 April.

There was a Time. I 5 April.

Blue Pauses. 29 April.

An Honourable Profession. 6 May.

The Loss is the Profit. I 3 May.

I977c Modern Aitu. Fiji Teachers' Journal (Suva) 4:I3-I4.

I977d Pebbles and Pauses. Pacific Perspective 6 (2): I-5.

I978a The Artist and the Reefs Breaking Open. Mana 3 (I): IO7-I2I.

I978b Kilikiti. Readers Digest. Nov.

1978c Report on the Tonga Regional Visual Arts Workshop, 22 Nov-Io Dec I976. Compiled by Albert Wendt. Lautoka: Universal Printing Press.

I980a Continuing Education and the University of the South Pacific. Directions (Suva) 4:I-4.

I980b In Search of Snow. Readers Digest.

I98Ia Art of the South Pacific. Gakkaishi: Journal of the Pacific Society (Tokyo) October (I 2): I-4.

I98Ib Don't Generalize About the Pacific. Aid Research Newsletter (Wellington) 3 (Sept): 4-6.

I98Ic Kuai Maueha of the Solomons. Mana 6 (2): 7I-77.

I98Id Western Samoa's First Strike: A Foreign Invention Which Becomes Samoan Overnight? Pacific Perspective Io (I): 45-56.

1983a Contemporary Arts in Oceania: Trying to Stay Alive in Paradise as an Artist. In Art and Artists of Oceania, edited by Sidney M Mead and Bernie Cairned, I98-209. Palmerston North, NZ: Dunmarra Press.

I983b Three Faces of Samoa: Mead's, Freeman's, and Wendt's. Pacific Islands Monthly 54 (4): IO-I4, 69.

I983C The Writer as Fiction. Mana 8 (I): 40-46. (Rp I984 Pacific Islands Communication Journal [Honolulu: Institute of Culture and Com- 
munication, East-West Center, and Suva: Pacific Islands New Association] I3 [I]: 4I-49; 1984 in Publishing in the Pacific Islands, edited by Jim Richstad and Miles M Jackson, 4I-50. Honolulu: Graduate School of Library Studies, University of Hawai'i.)

I985a Oceania and the New Artists. In Asia and Japan: The Search for Modernization and Identity, edited by Andrew J L Armour, I 20I34. London: Athlone Press; Tokyo: Keio University.

I985b Time NZ Added Polynesia to Colonial Hue [report of keynote address to education forum]. РРТА News (Wellington) 6 (9 [July]): 4 .

I985c We Are What We Remember [report on Wendt's address to the Pacific History Conference, University of the South Pacific, Suva]. Bulletin (USP) I 8 (25): I-2. (Rp Fiji Sun, I 3 July, as Most Islanders Know Little of Their Histories.)

I987a Novelists and Historians and the Art of Remembering. In Class and Culture in the South Pacific, edited by Antony Hooper and others, 78-92. Suva: Institute of Pacific Studies.

I987b W. Samoa 25 Years After: Celebrating What? . . Pacific Islands Monthly 58 (6): I4-I 5 . (Rp I987 Search [usp Centre, Rarotonga] I [4]: I-3 [with rebuttal from Western Samoan Attorney General Misa Foni Retzlaff, reprinted from Albert Wendt, 25 Years After: Commiserating What? The Samoa Observer (Apia), 24 June: 3 , 5].)

I990 An Interview with Festus Iyayi (with Sebastian Black). Landfall $44(4): 4$ I 2-422.

I99I Pacific Maps and Fiction(s): A Personal Journey. In Perceiving Other Worlds, edited by Edwin Thumboo, I79-210. Singapore: Times. (Rp 1995 Meridian I 4 [2]: 13-44. Also 1995 in Asian \& Pacific Inscriptions: Identities, Ethnicities, Nationalities, edited by Suvendrini Perera, I3-44. Bundoora: Meridian [LaTrobe University]).

1992 Discovering “The Outsider.” In Camus's L'Etranger: Fifty Years On, edited by Adele King, 48-50. New York: St Martins Press.

I996a Imaging the Pacific [talk]. Melbourne Writers Festival, I 8 Oct.

I996b Tatauing the Post-Colonial Body. Span 42-43 (April): I 5-29.

I999 Afterword: Tatauing the Post-Colonial Body. In Inside Out: Literature, Cultural Politics, and Identity in the New Pacific, edited by Vilsoni Hereniko and Rob Wilson, 399-4I 2. Lanham, MD: Rowman \& Littlefield. 
2000a Grandchildren and the Uncertainty Monster. In Grand Stands: New Zealand Writers on Being Grandparents, edited by Barbara Else, 5 I-74. Auckland: Vintage.

$2000 \mathrm{C}$ The Treaty, A Personal Journey. In Proceedings of Treaty Conference 2000, Sacred Heart College, Glen Innes, Tamaki Makaurau I Auckland, 6-8 July 2000, 28-32. Auckland: Treaty Conference 2000 Publication Group.

\section{INTERVIEWS WITH / Profiles OF WendT}

Alaisa, Sam L

I982 Excerpts from an Interview Between Professor Albert Wendt of the School of Education and the Editor of UNISPAC. UNISPAC (The University of the South Pacific Students Association), July-Sept: 32-35.

Anonymous

1973 Guest of Honour. NZTV, Nov.

I980 Albert Wendt zu Gast: Besuch aus Samoa: Kunst und Literatur im Pazifik. Publik: Kasseler Hochschulzeitung (Kassel, Germany), 2 July: I.

I982a Rich Traditions Kept Up By Samoans in New Zealand. New Zealand Herald, 27 Sept.

I982b Wendt Focuses on Islanders in Auckland. Auckland Star, 28 April.

I987 Cultural Strands Tied Together with Pen. Cook Islands News, I7 Jan: 8-9.

I99I Writing Fascinates Samoan Author. Contact (Suva), i I July.

Beston, John, and Rose Marie Beston

I977 Interview with Albert Wendt. World Literature Written in English I6 (I): I $5 \mathrm{I}-\mathrm{I} 62$.

Chapple, Geoff

I99I Wendt Ends the Silence. Sunday Star (Auckland), 23 June: C I. Cole, Shari

I987 Albert Wendt's Personal Approach to the Novel. Tusitala (Polynesian Airlines) Summer: I4-I 5.

Crocombe, Marjorie Tuainekore

I973 Pacific Personality: Samoa's Albert Wendt, Poet and Author. Mana Annual of Creative Writing I:45-57. 
Davidson, Jim

1978 Albert Wendt. Meanjin 37 (I): I09-I I 8. (Rp I983 in Sideways from the Page: The Meanjin Interviews, edited by Jim Davidson, 7I-84. Melbourne: Fontana/Collins.)

Dor, Moishe

I98I How Do You Say “Telephone” in Samoan? [commentary, poem and story]. Ma'ariv (Israeli newspaper), 20 June: $38-39$.

Durix, Jean-Pierre

I993 The Travels of a Tusitala: Albert Wendt in Burgundy. Common-

Edo, Junko wealth: Essays and Studies I 6 (2): 7-9.

I98I People. Daily Yomiusi (Tokyo), 30 June.

Ellis, Juniper

I997 The Techniques of Storytelling: An Interview with Albert Wendt. Ariel: A Review of International English Literature 28 (3): 7994 .

Eriksson, Jörgen

I989 Mytisk Realist. Dagens Nyheter, I 5 Jan: 7.

Field, Michael

I98I Wendt Looks at a Fight for Survival. Post (Wellington), I7 Aug. Flanagan, Martin

I986 Continuing a Cultural Tradition. The Age (Melbourne), 6 Sept. French, Blair

I989 Albert Wendt: A Post-Colonial Pacific. CANTA (University of Canterbury, Christchurch) 58 (24), 3 Oct (np).

Gordon, Audrey

I975 Big Talent from a Small Place. NZ Woman's Weekly, I3 Jan: 6-7.

I979 Fame from Screen and Printed Work. NZ Women's Weekly, 8 Oct: $68-70$.

Gribben, Trish

I974 A Voice from Samoa. Eve, January: 9.

Hereniko, Vilsoni

I993 Following in Her Footsteps: An Interview with Albert Wendt. Manoa 5 (I): 5 I-59.

Hereniko, Vilsoni, and David Hanlon

I993 An Interview with Albert Wendt. The Contemporary Pacific 5:I I 2-I3I. (Rp I999 in Inside Out, Literature, Cultural Politics, 
and Identity in the New Pacific, edited by Vilsoni Hereniko and Rob Wilson, 85-I04. Lanham, MD: Rowman \& Littlefield.)

Iyechad, Gwenda L

I992 Listen to the Call of the Isles. Honolulu Star Bulletin, Io Feb: B I.

Lam, Dana

I980 Samoa's Lone Novelist Who Yearns for a Quiet Life. The Straits Times (Singapore), 27 June: 3.

Macdonald, Iain

1973 "Of course" He Was Called a Coconut. New Zealand Herald, Io Nov, section 2: 5 .

McLauchlan, Gordon

I979 In Vanguard of Art Revolution. New Zealand Herald, 27 Oct, section 2: 4 .

Miller, Paul

I999 Interview. New Zealand Books 9 (3): I2.

Neill, Michael

I992 Albert Wendt. In In the Same Room: Conversations with New Zealand Writers, edited by Elizabeth Alley and Mark Williams, IOI-I I8. Auckland: Auckland University Press.

Paga, John

I986 Mind-bending: Wendt's Return Shock. Sunday Star (Auckland), I 3 July: C4.

Paske, Helen

I978 Albert Wendt Shakes the Shackles of the Past. New Zealand Listener, 25 March: 24-25.

Rampell, Ed

1990 An Angry Man. Pacific Islands Monthly 60 (I): 55-57.

Ritterbusch, Deacon

I982 Albert Wendt: Interview. Impulse (East-West Center) 9 (I):2830.

Robyns, Sian

I99I Playing Literary Games. Dominion (Wellington), 6 July: 7 . Rolfe, Patricia

I986 The Saga of Samoa. The Bulletin (Sydney), I6 Sept: 69.

Sarti, Antonella

I998 Albert Wendt. In Spiritcarvers: Interviews with Eighteen New Zealand Writers, edited by Antonella Sarti and Christopher B Evans, 207-2 I2. Amsterdam: Rodopi. 
Segerberg, Anita

I982 Litteraturen I Söderhavet. Svenska Dagbladet (Stockholm), 24 March.

Singh, Kirpal

I980 Albert Wendt: The Voice of a People. Sunday Times (Singapore), 6 July.

Spalding, Linda, and Frank Stewart, editors

I980 The Return Home: A Dialogue with Albert Wendt. In Interchange: A Symposium on Regionalism, Internationalism and Ethnicity in Literature, 70-79. Honolulu: Interarts.

Strahl, Rudi, and Werner Liersch

1978 So Genau Wie Moglich: Gesprach mit Albert Wendt. Neue Deutsche Literatur (Berlin) 26 (4): 42-47.

Tarte, Sandra

I987 Samoa's Wendt Signs Off in Suva. Islands Business I 3 (5 [May]): 48.

Trower, David.

I990 Albert Wendt: Writer. Auckland Star, 8 Oct: B 5 .

Tyler, Janet

I995 Island Treasure. Quote Unquote (Auckland), 26 Aug: I I. van Dongen, Yvonne

I987 Looking Forward to Another Return Home. Sunday Times (Wellington), 4 Jan: I3.

Wayne, Joanna

I99га Bard of Polynesia. TV Viewer, I 5 Feb: 36-39.

I99Ib Painful Echoes from Real Life. NZ Women's Weekly, 23 Sept: 90-9I.

Woodhouse, Annabelle

I986 Living in the Lap of Luxury. NZ Women's Weekly, 7 July: 8-9. Zavos, S B

I974 Samoan Writer with Mark of Literary Lion. Dominion, 3I Dec.

Reviews/Articles on Specific Books

Plays

Anonymous

I968 Revolution Comes to Western Samoa. Pacific Islands Monthly 39 (Iо): 30. (Also published in Auckland Star as Samoan Play- 
wright's First Effort Lauded, and in another New Zealand paper [Dominion?] as First Samoan Playwright.)

Sons for the Return Home [novel]

Anonymous

1972 Samoan Novelist. Pacific Islands Monthly 43 (I 2): 25.

r973a Pains of a New Chum. Dominion Sunday Times (Wellington), 2 Dec.

1973b Racialism. Northern Advocate (Whangarei), 5 Nov.

I973c Review. The Press (Christchurch), 24 Nov.

I973d Review. Waikato Times (Hamilton), i 8 Dec.

1973 e Search for Truth in Human Relations. Sunday Herald (Auckland), 9 Dec: 46.

I974 Review. English in New Zealand July: 56-57. [probably by Bernard Gadd]

Arvidson, Ken O

I974 Review of Albert Wendt's Sons for the Return Home. Landfall $28(3): 256-260$.

Ashcroft, W D

I98I The Place of the Spirit: Albert Wendt's Sons for the Return Home. New Literature Review 9:24-33.

B, D G

I973 Literary Horizons Expand Samoan and Maori Authors. Otago Daily Times, 2I Nov.

B, J

I974 Poignant Love Story with a Message. Christchurch Star, 26 Jan. Brett, Michael

I973 By Teaching and Example, A Voice for Samoa. Auckland Star, 5 Nov.

Ellis, Juniper

I998 Return to Exile: Locating Home. Jouvert: A Journal of Postcolonial Studies (electronic publication) 2 (2): 58. $<$ http://social.chass.ncsu.edu/jouvert/v2i2/con22.htm>

England, Katherine

I974 Voice of the Third World. Advertiser (Adelaide), I I May. Enos, Theresa

I982 Review. Commonwealth Novel in English I (2): 23 5-237.

Field, Kingsley

I973 Review. Waikato Times, I8 Dec. 
G, M L

I973 A Revealing Scrutiny of New Zealand. Nelson Morning Herald, 24-25 Nov.

Gordon, Audrey

I973 Review. NZ Women's Weekly, I9 Nov.

Harlow, Jenny

I973 Review. Today's Book (radio program), NZBC, 28 Nov.

Hastings, Peter

I974 Young Lovers Trapped in Cultural Conflicts. Sydney Morning Herald, 27 July: I 5.

Hewitt, Hope

I973 Two Trendy Novels. Canberra Times, 20 Sept.

Ihimaera, Witi

1973 Review. New Zealand Bookworld 6 (Nov): I 5-I6.

Katene, Paul

I974 Review. Te Ao Hou (Wellington) 75 (March): 62-63.

Langby, Jenny

I979 Real-life Drama in "Sons." Hawkes Bay Herald, 24 Nov.

Lawler, Margaret

I973 Every Migrant's Dream. Auckland Star, Io Nov, Weekender section: I I.

Locke, Elsie

I974 Forever Divided. Islands 8, 3 (2): 229-23I.

$\mathrm{M}, \mathrm{H}$

I979 Review. Wanganui Herald, I Nov.

M, W E

I973 Wendt's First Book Has Touches of Greatness. Bay of Plenty Times, 27 Oct.

McCracken, Jill

I973 Samoan Sons. New Zealand Listener, Io Nov: 44.

Moore, G

I980 Review. New Zealand Bookworld 57 (March): I4-I 5.

Te Morehu, $\mathrm{Na}$

I973-I974 Review. Rongo (Auckland)I (I [Summer]): I3.

Murphy, Julie

I973 Sons for the Return Home: A Review. UNISPAC 6 (5): I 2.

Mutter, John

I987 Note. Publishers Weekly 23I, I2 June: 8I. 
Pearce, J R

1973 New Zealand in Samoan Eyes. New Zealand Herald, 27 Oct. Richardson, Helen M

I973 Polynesian Publications. Southland Times (Invercargil, NZ), 26 Nov.

Ruhen, Olaf

I975 First Samoan Novel of Classic Beauty. Pacific Islands Monthly 45 (I): 68-69.

V, F

I973 Sons for the Return Home. Samoan Times (Apia), 23-29 Nov. Valtiala, Nalle

I974 Perspektiv pa Samoa. Hufvudstadsbladet (Helsinki), Io Sept. Vile, John

I974 A Pair of Firsts from New Zealand. Fiji Times (Suva), I 8 May.

Booklets of Poetry

Subramani

1976 Two Poetry Anthologies for Fiji: Review, Some Modern Poetry from Fiji, and Waves. Mana Review I (I): 75-78.

Flying-Fox in a Freedom Tree [short stories]

Adams, Graham

I988 Books. Tempo 26, I2 Feb: I 2.

Anonymous

I974 Stories of Samoa by Albert Wendt. Waikato Times, I6 Dec.

I975 Palagi and Samoan Culture. The Press, 22 Feb.

I988 Review. North Shore Times Advertiser, 3 May.

Armstrong, Lindsay

I988 Nine Short Stories by Albert Wendt. Waikato Times, 29 Oct. Arvidson, Ken O

I975 Review of Albert Wendt's Flying-Fox in a Freedom Tree. Landfall 29 (I): 72-76. (Rp I976 in Mana Review I [I]: 7I-74.)

Bardolph, Jacqueline

I98I Narrative Voices, Narrative Personae, in Flying-Fox in a Freedom Tree. Echos du Commonwealth 8:69-83.

C, W P

I975 Review Time. Wanganui Herald, 25 Jan.

Carrington, Don

I975 Flying-Fox in a Freedom Tree. Samoa Times (Apia), 2 I March: 4 . 
Corney, Robin

I988 Paperbacks. Dominion Sunday Times, I 3 March: I 8.

Cruickshank, John

I976 Flying-Fox in a Freedom Tree. Samoana Herald (Auckland), 5 Feb.

Cummingham, Kevin

I975 Review of Albert Wendt's Flying-Fox in a Freedom Tree. New Zealand Bookworld I 5:35-36.

Gibson, Colin

I988 Tales from the Pacific. Dunedin Star, ro April, Weekender: I2. Guiart, Jean

I975 Review of Flying-Fox in a Freedom Tree by Albert Wendt. Journal de la Société des Océanistes 31:497-498.

Haycock, Gavin

I988 Colourful Collection by Skilled Storyteller. Northern Advocate, 20 Feb, Leisureweek.

Hulston, Dennis

I980 A Note on Albert Wendt's Flying-Fox in a Freedom Tree. Kunapipi 2 (I): 96-I05.

King, Michael

I975 Eagle in the Gut. New Zealand Listener, 29 March: 30.

Lawler, Margaret

I975 Visa Extended. Auckland Star, 5 Jan.

Racule, Rejieli

I976 Flying-Fox in a Freedom Tree by Albert Wendt. UNISPAC 9 (I): 7 .

S, S

I990 Contradictions and Hypocrisies in Flying-Fox in a Freedom Tree. Illusions I 4:6-7.

Samasoni, Samson

I988 Pacific's King and Court Jester. Evening Post, 30 Jan. Scott, Gary

I988 Review. Nexus I2 (2 [March]): Io.

Inside Us The Dead: Poems 1961-1974

Anonymous

I976 Review. Multicultural School 6:48.

I977 Two Baxter Collections Emphasize His Talent. Otago Daily Times, 9 March. 
Beston, John B

I976 Review of Albert Wendt's Inside Us the Dead: Poems I96I-I974 (Auckland: Longman Paul, I976). Mana Review I (2 [Dec]): $75-78$.

I977 Alofa: Pacific Literature Stresses Polynesian Values. Sydney Morning Herald, I9 March.

Beston, Rose M

I977 The Poetry of Albert Wendt. World Literature Written in English I6 (I): I63-г68.

de Bres, Joris

I976 Review. City News, I4 Dec: 24.

Caffin, Elizabeth

I977 Our Voices from Foreign Places. The Press, 26 Feb.

Fisher, Graeme

I977 Samoan Aspect. Auckland Star, I 2 Feb.

Malifa, Sano

I977 Searching Homeward. Samoa Times, 7 April: I 5.

Paterson, Alistair

I977 Review of Albert Wendt's Inside Us the Dead, Poems I96I1974. New Zealand Bookworld 36:20-22.

Roddick, A

1977 Politics in Paradise. New Zealand Listener, 25 June: 56-57.

Simpson, Peter

I977 Review of Inside Us the Dead. Landfall 3I (2): I 8I-I85.

Toft, R

I978 Review. Outrigger 2 (5 [Sept]):35-4I.

Volkerling, Michael

I976 Poems of a Pacific Voyager. Sunday Times, I9 Dec: 27.

Pouliuli [novella]

Anonymous

I98Ia Note. Kliatt (US paperbacks guide), Spring: I6

I98Ib Note. Library Journal, I 5 Feb, 473.

I987 Review. Nexus, I3 April.

Auva'a, Fa'alafua L

I997 The Cultural Perspective of Albert Wendt's Novel Pouliuli. MA thesis, Department of English, Utah State University.

Bertram, James

I978 Samoan Lear. New Zealand Listener, 25 March: 54-55. 
Beston, John

1978 Samoa: A Far Cry from Margaret Mead. Sydney Morning Herald, I 8 March.

I979 Albert Wendt's Pouliuli. World Literature Written in English I 8 (I): I 44-I 49.

Chadwick, Joseph.

I989 Allegories of the Novel in Albert Wendt's Pouliuli. In Comparative Literature East and West: Traditions and Trends. Selected Papers, edited by Cornelia N Moore and Raymond A Moody, I55-I6I. Honolulu: University of Hawai'i College of LanCrisp, Peter guages, Linguistics and Literature, and the East-West Center.

I979 Albert Wendt: Pathways to Darkness. Islands 267 (4): 374-385. Doetschman, Sarah J

I998 Imagining the Future: Restructuring Identity in Pouliuli and Maiba. World Literature Today: A Literary Quarterly of the University of Oklahoma 72 (I): 83-88.

Dutton, Geoffrey

I978 A Disturbing Darkness Amid the Sunshine. The Bulletin, 9 May: 69.

Hingley, Bert

I977 Mention in Bookmarks column. New Zealand Listener, 9 April: 37.

Jackson, Miles M

198I A Samoan Novella by Albert Wendt. Pacific Information and Library Services Newsletter 4 (3): 3 .

Larson, Charles

I978 World Literature Today 52 (2 [Spring]): 247.

Lodge, Sally

I980 Note. Publishers Weekly, 31 Oct: 83.

Lorenz, Paul H

I994 Sleep On, My Friend, While the World Dreams of Terror: Albert Wendt's Pouliuli. Publications of the Arkansas Philological Association 20 (I): 65-77.

McLauchlan, Gordon

I977 Writer Who Likes Taking Risks. New Zealand Herald, I 2 Nov, section 2: 4 .

Ruhen, Olaf

I979 Wendt Lives Up to His Promise. Pacific Islands Monthly 50 (3): $4 \mathrm{I}-42$. 
Simms, Norman

T, $\mathrm{N}$

I978 Review of Pouliuli. World Literature Today 52 (4): 696-697.

I987 Imagery, Use Powerful. Daily Post (Rotorua), 29 July.

Tiffin, Chris

I978 Review. Mana 3 (I): I40-I42.

Tiffin, Helen

I978 More Myth Than Dog. Review of Albert Wendt's Pouliuli. Span 6:53-57.

Leaves of the Banyan Tree [novel]

Ableman, Paul

I980 Reflections on the Novel. Spectator, I4 June: 2 I-22.

Alcock, Peter

I980a Review. Comment I I (June): 32-33.

I980b Review of Albert Wendt's Leaves of the Banyan Tree. Kunapipi 2 (I): I75-I78.

Allen, Kimberley G

I994 Review. Library Journal I I9 (I3): I35.

Anonymous

1980a Literary Review 9, 22 Feb. [also cited as Pacific Quarterly]

I980b No Leaves Unturned. New Zealand Truth, 8 April.

198I British Book News, Sept: 515. Plus many syndicated notes in UK provincial papers.

I983a Drohung und Faszination Europas. Neue Welt (Munich), Io Jan. [German edition]

I983b Note. Kirkus (New York), I I Nov.

I983c Note. Publishers Weekly, I I Nov: 42.

I984a Banyan Slow Going. Anniston Star (Alabama), 5 Feb.

Arvidson, Ken O

I980 Sons of the Father. New Zealand Listener, ıо May: 68-69. Bass, Judy

I984 Paradise Lost to Man's Greed. Boston Herald, 22 Jan: Io6. Bennington, Seddon

I980 Casting an Eerie Shadow. New Zealand Bookworld 60 (DecJan): I $2-13$.

Blow, Simon

I980 Cocktail Drugs. New Statesman, 6 June: 854 .

Durix, Jean-Pierre

I98I Power in Leaves of the Banyan Tree. Echos $d u$ Commonwealth 8:84-107. 
Dutton, Geoffrey

I980 Stripping the Myths from Western Samoa. The Bulletin, I6 Dec: 78.

Edmond, Murray

I980 Review of Leaves of the Banyan Tree. Islands 8 (2): I66-I73.

Eldridge, Marian

I982 Review. Muse (Canberra): 35 .

Farrell, Fiona

I988 Vivid Scenes In Wide-angle. Evening Post (Wellington), I 8 June.

Findlayson, Iain

I980 Sugared Pills in Suburbia. Glasgow Herald, 3 I May.

French, Blair

I988 Review. CANTA (Christchurch), May (np).

Hamasaki, Richard

I984 The Banyan. Ka Huliau (Honolulu), April-May: I3.

Hill, David

I979 Obsession and Loss. Star (Auckland), 8 Dec, Weekender: 8.

Holing, Dwight

I984 The Meaning of a Family Farm's Loss. San Francisco Chronicle, 25 March: 5 .

Italiaander, Rolf

I983 Klagen über Bibel, Münze und Gewehr. Die Welt (Hamburg), I 8 June [German edition].

Jeffares, A N

I980 Review. British Book News, Sept: 567.

Jones, Karyl C

I994 The Appropriation and Reappropriation of the Feminine in Leaves of the Banyan Tree and the bone people. Paper presented at the conference, From the Inside Out: Theorizing Pacific Literature, Honolulu, I4-I7 Sept.

Keesing, Nancy

I980 The Forsytes of Samoa. Sydney Morning Herald, I3 Dec, The Good Weekend: 43.

Keown, Michelle

2002 The Samoan Sisyphus: Camus and Colonialism in Albert Wendt's Leaves of the Banyan Tree. Journal of Commonwealth Literature 37 (I): 49-64.

King, Bruce

I98I Review. World Literature Written in English 20 (2): 37 I-373. 
Madhavan, Vimal

I987 Review. Business News (South Pacific), May.

McGavran, James $\mathrm{H}$

I984 Adopting Western Ways Not Easy. Columbus Despatch, 25 March.

McMahon, Sean

I980 Fiction in Brief. The Hibernian, 7 Aug.

Miller, Jill

I980 Eloquent and Sensitive Work. Hawkes Bay Herald-Tribune, 5 April.

Murphy, Marese

I980 Not Quite Caviar. Irish Times, 2I June.

Najita, Susan

200I Colonial Resistance in Albert Wendt's Leaves of the Banyan Tree. Unpublished paper, 13 th Triennial Congress, Association for Commonwealth Language and Literature Studies, Canberra, July.

Nightingale, Margaret

I98I Saving the Banyan. CRNLE Reviews Journal I (May): 55-56.

1982 Roots Against the Hurricane. CRNLE Reviews Journal 2 (Dec): 77-8I.

Pearson, Bill

I980 Village and World. Islands 268 (2): I66-I70.

Price, Victor

I980 A Novelist from the South Pacific. в в с Central Talks and Features, Book Talks, 30 May.

See, Carolyn

I984 Growing Rich in a Ramshackle Paradise. Los Angeles Times, 2 Jan: 8.

Simpson, Peter

I982[?] Great-rooted Blossomer. The Press, 2 I Nov.

Smith, Mike

I979 South Pacific Writer Turns Out an Epic. Waikato Times, I 3 Nov. Tawake, Sandra

I995 Leaves of the Banyan Tree. Manoa: A Pacific Journal of International Writing 7(I): 263-264.

Tiffin, Chris

I979 Review of Albert Wendt's Leaves of the Banyan Tree and Lali. Span II: 50-55. 
Unger, Susan

I984b Review. Library Journal, I Feb: I93.

Ward, Elizabeth

I983 Seeking Solace in Samoa. New Zealand Bookworld, 25 (Dec): I, 3 .

Wertheim, Albert

I984 Leaves of the Banyan Tree: Coming of Age of Samoa. World Literature Written in English 24 (2 [Autumn]): 443-449.

Zavos, Spiro

I980 The Staying Power of a Literary Lion. Pacific Islands Monthly 5I (9): 39 .

Lali [anthology]

Alcock, Peter

I98I The Kava Is Rising. Comment I4 (Nov): 35-36.

Anderson, Roland F

I98I Review. World Literature Written in English 20 (2): 368-370.

France, Jean

I98I Pacific Stories and Poems. Southland Times, 28 March.

Hill, David

I980 Pacific Attitudes. Auckland Star, 8 Nov.

James, Trevor

I98I Pacific Writing. Landfall 35 (3): 287-292.

L, N A

I980 Stories Show Utter Honesty. Daily Telegraph, 5 Nov: I 5.

Perry, Gwyneth

I980 Review. Whakatane Beacon, I2 Oct.

Sharrad, Paul

I98I A Hopeful Retrospect. CRNLE Reviews Journal 2 (Dec): 85-86. Simms, Norman

I982 Review. World Literature Today 56 (I): I79-I90.

Simpson, Peter

I98I Speaking Out From Pacific Islands. The Press, 9 May.

Tiffin, Chris

I979 Review of Albert Wendt's Leaves of the Banyan Tree and Lali. Span I I: 50-55.

Truell, Toby

I98I Springs of Island Feeling. New Zealand Bookworld 6 (Feb): 28. 
W, Z

I980 Unbeatable Interest and Variety. The Daily Post (Rotorua), I9 Nov: 22.

Zavos, Spiro

I98I Islanders' Own Gong Sounds At Last. Pacific Islands Monthly 52 (I): 47 .

Shaman of Visions [poetry]

Amanuddin, Syed

I985 Review. World Literature Today, Summer: 490.

Arvidson, Ken O

I986 Before the First Word. New Zealand Listener, 20 Sept: 8I-82. Mishra, Sudesh

I989 That Hound of Imagination. CRNLE Reviews Journal I:83-85.

O'Donoghue, Bernard

I986 Urgent Disputations. Times Literary Supplement, 5 July: 753.

Birth and Death of the Miracle Man [stories]

Anonymous

I987 Review. World Literature Today 6I (Winter): I6I.

Bertram, James

I986 A Voice of Samoan Detachment. Dominion, I 2 July: 9.

Crace, Jim

I986 The Rot in Samoa. Times Literary Supplement, 23 May: 552.

Faulkner, Heather

I986 A Series of Passing States. Weekend Australian, 20-2I Sept.

Graham, Susan

I986 Gentler Wendt Rich in Insight. New Zealand Herald, 20 Sept, section 2: 6 .

$\mathrm{H}, \mathrm{F}$ A

I986 Humour, Insight in Samoan Stories. Bay of Plenty Times, I3 Sept.

Hamilton, Alex

I987 Paperbacks. The Guardian, 27 March.

Hanrahan, John

I986 Two Clouds Over Samoa. National Times (Sydney), 3I Aug.

Heath, Robert

I986 Review. Drumbeat, Dec: 5.

Heron, Liz

I986 Lost in the Labyrinth. New Statesman, 28 Feb: 27 . 
Hill, David

I986 Rich Brews. Sunday Star, I 3 July: C4

Mason, Deborah

I986 Review. New York Times Book Review, 3 Aug: I 8.

McLean, Gavin

I987 Rabelaisian Explosions and Pacific Smells. Otago Daily Times, 30 Sept: 28.

Minol, Bernard

I988 The Birth and Death of the Miracle Man and Other Stories. Ondobondo (Boroko, PNG) 9:47.

Misa, Tapu

I986 Review. More 40 (Oct): 239-240.

$\mathrm{N}, \mathrm{W}$

I989 Last Page. Canadian Literature, Summer: 209.

Neill, Michael

I987 A Cultivated Innocence. Landfall 4I (2): 2I3-2I9.

O'Rourke, Valerie

I992 A Tribute to the Fa'a Samoa: Albert Wendt's Birth and Death of the Miracle Man. World Literature Today 66 (I): 5I-55.

Sharp, Iain

I986 Books in Brief. New Outlook (Auckland), Sept/Oct: 60.

Stuttaford, Genevieve

I986 Forecasts. Publishers Weekly, 6 June: 56

Theobald, George

I987 Another land. New Zealand Listener, 4 April: 65.

Turner, George

I986 Joyful Discoveries in Cool, Beautiful Prose. The Age (Melbourne), 6 Sept: $\mathrm{I} 2$.

Wigston, Nancy

I986 The Fabled Islands. Toronto Globe and Mail, 23 Aug.

Ola [novel]

Aoki, Diane

I993 Review of Ola. The Contemporary Pacific 5:456-459.

Brenstrum, Erick

1992 Ambitious Novel on a World Stage. New Zealand Books 2 (I): 2.

Creagh, Carson

I99I Rarely Lifts Itself Above a Rant. New Zealand Listener, 29 July: $45-46$. 
Dixon, Ian

I99I The Permissions of Ola. The Press, I7 Aug: 26.

Eggleton, David

I99I Novel's Burden Too Heavy To Bear. Evening Post (Wellington), 28 June: 5 .

Gabriel, Sharmani Patricia

1992 All Is Reality: Samoan Delivery. CRNLE Reviews Journal I:2326.

Howard, A

I99I Review. More 98 (Aug): I47-I48.

Isaacs, Clarke

I99I Familiar Settings for Fiction. Otago Daily Times, 5 Oct: 2 I. King, Michael

I99I Review. Metro, July: I34-I35.

Lay, G

I99I From the Village to the World. North and South, August: I 22. Oxenham, $\mathrm{S}$

I996 Review. World Literature Today 70 (2): 477.

Reid, Graham

I99I Visionary World of Albert Wendt. New Zealand Herald, 20 June, Thursday Morning section 2: I.

Rigby, Nigel

I992 Review. Wasafiri I6 (Autumn): 66-67.

Roberts, Heather

I99I A Voyage of Self-Discovery that Founders. Dominion Sunday Times, 30 June: 22.

Shadbolt, B

I99I Review. Print 22 (Aug): 24.

Sharrad, Paul

I992 Substantive Act. Landfall 46 (I): I I3-I I6.

Simms, Norman

I992 Ola. Manoa: A Pacific Journal of International Writing 4 (2): 219.

Simpson, Peter

I99I Wendt Chisels Hardest Stone. New Zealand Herald, I 3 July, section 2: 6 .

Williams, Mark

I99I Wendt's New Novel Goes International. Dominion, 6 July: 7 . 
Black Rainbow [novel]

Broughton, William

I992 Futuristic Allegory Deceptively Simple. Dominion Sunday Times, 23 Aug: 20.

Coogan, Phil

I992 In-jokes for Erudite. New Zealand Herald, 29 Aug, section 2: 2. DeLoughrey, Elizabeth

I999 Towards a Post-Native Aiga: Albert Wendt's Black Rainbow. In Indigeneity: Constructions and Re/Presentations, edited by James N Brown and Patricia M Sant, I37-I 55. Commack, NY: Nova Science Publishers.

Dixon, Ian

1992 Brave New World in New Zealand. The Press, I9 Aug, supplement: Io.

Eggleton, David

I992 An Exotic Blend That Doesn't Quite Come Off. Evening Post, 7 Aug: 5 .

Ellis, Juniper

I994 A Postmodernism of Resistance: Albert Wendt's Black Rainbow. Ariel 25 (4): IOI-I I4.

I997 Review. World Literature Today 7I (I): 232-233. Else, Chris

1992 Cryptic Crosswords and Intellectual Judo. New Zealand Books $2(3): 8$.

Garrett, Simon

I992 Wendt Looks to the Future. Dominion, I Aug: I I.

Neill, Michael

I992 Review. STAMP 34 (Sept): 44.

Nerney, Frank

I992 Blundering From One Adventure to Another. Listener and TV Times, 8 Aug: 5 $1-52$.

Photographs [poems]

Eggleton, David

I995 Away From Home. New Zealand Books 5 (4): 9-Io.

Newton, J

I995 Review. Evening Post, 25 Aug: 5.

Riach, Alan

I996 Review. Landfall ns 4 (I): I77-I79. 
Sharp, Iain

I996 Review. Printout I I:73-74.

White, Helen Watson

I996 Review. Poetry New Zealand I 2:65-69.

Wyatt, Hamesh

I995 Review. Otago Daily Times, 2I Oct: 2 I.

Nuanua [anthology]

Arvidson, Ken O

I995 Review. Evening Post, 28 April: 5

Cooper, Rhonda

I995 Books. Metro, Sept: I33.

Finlay, Rob

I995 Review. New \& Notable I2 (3): 2 I-26.

Laracy, Hugh

I995 Review. New Zealand Herald, I 5 July: 8-9.

O’Neill, Rob

I995 I Do Declare. Quote Unquote, 27 Sept: 29.

Rigby, Nigel

I996 Review. World Literature Today 70 (I): 237-238.

Ryan, Yoni

I996 Review. Journal of Pacific History 3I (I): I 22-I 23.

Sharrad, Paul

I995 Review. Span 40 (April): IOI-IO3.

Tawake, Sandra

I997 Review of Nuanua. Wasafiri 25 (Spring): 89-90.

Thompson, Christina

I995 Review. Landfall ns 3 (2): $32 \mathrm{I}-324$.

The Best of Albert Wendt's Short Stories

Arvidson, Ken O

I999 Review. Evening Post, 2 July: 5.

Birnie, John

I999 Review. Otago Daily Times, 25 Aug: 24.

Eggleton, David

I999 Review. New Zealand Listener, Io July: 42-43.

McEldowney, David

I999 Review. New Zealand Books 9 (3): I3.

Millar, Paul

I999 Review. Dominion, 24 July: 20. 
Sharp, Iain

I999 Review. Sunday Star Times, 27 June: F 2.

Stafford, Jane

2000 Review. Landfall ns 8 (I): I33-I35.

Other

Anderson, Roland F

I984 Review of the Special Issue of Echos du Commonwealth (No. 8, I982) on Albert Wendt. World Literature Written in English 23 (2 [Spring]): 496-500.

Studies Focusing on Wendt

Bardolph, Jacqueline

I984 Albert Wendt: A New Writer from Oceania. In A Sense of Place: Essays in Post-Colonial Literatures, edited by Britta Olinder, 42-56. Göteborg: University of Gothenberg.

Bell, Richard A

I998 Cultural Exchange in Two Wendt Films: Sons for the Return Home and Flying-Fox in a Freedom Tree. MA thesis, Art History, University of Auckland.

Benson, Cliff

I990[?] Albert Wendt [study guide for secondary students]. Suva: Institute of Education, University of the South Pacific.

Beston, $\mathrm{R}$

I977 The Poetry of Albert Wendt: Western Samoa. World Literature in English I6 (I): I63-168.

Chi, Robert

I997 Toward A New Tourism: Albert Wendt and Becoming Attractions. Cultural Critique 37 (Fall): 6I-105.

Connell, John

I993 The Return Home? Albert Wendt, Migration and Identity in Polynesia. Working Paper 92/23. Leeds: School of Geography, University of Leeds.

I994 In Samoan Worlds: Culture, Migration, Identity and Albert Wendt. In Writing Across Worlds: Literature and Migration, edited by Russell King, John Connell, and Paul White, 263-279. London and New York: Routledge.

Durix, Carole

198I Networks and Itineraries in Albert Wendt's Poetry. Echos $d u$ Commonwealth 8:27-37. 
I996 Man and His/story in the Poetry of Albert Wendt. In The Contact and the Culmination, edited by Marc Delrez and Bénédicte Ledent, 293-304. Liège: Liège Language and Literature.

Durix, Carole, and Jean-Pierre Durix

I993 Introduction to Wendt and Selected Passage. In New Literatures in English, edited by Carole and Jean-Pierre Durix, I05-107. Paris: Longman France.

Durix, Jean-Pierre

I98Ia Foreword. Echos du Commonwealth 8: I-3.

I99I Albert Wendt: The Attempt to Snare the Void and Give It Word. In International Literature in English: Essays on the Major Writers, edited by Robert L Ross, 63-73. New York: Garland Publishing.

2002 The Sky-Piercers, Lions and Aitu: Missions and "Traditions" in Albert Wendt's Vision of a New Pacific. In Missions of Interdependence: A Literary Directory, edited by Gerhard Stilz, 39I402. Amsterdam: Rodopi.

Ellerman, Evelyn

I989 Intertextuality and the Fiction of Camus and Wendt. In Comparative Literature East and West: Traditions and Trends. Selected Conference Papers, edited by Cornelia N Moore and Raymond Moody, 43-50. Honolulu: University of Hawaici College of Languages, Linguistics, and Literature, and the EastWest Center.

Guiart, Jean

I993 Albert Wendt's Anthropological Truth. Commonwealth: Essays and Studies I 6 (2): 38-43.

Hereniko, Vilsoni

I997 Tataus and the Post-Colonial Body. Honolulu Weekly 7 (23): 6-8.

Isernhagen, Hartwig

I984 Nationale Geschichte und Internationale Kultur: Zur Problematik Neuer Englischsprachiger Literaturen (am Beispel Albert Wendt). In Anglistentag 1983 Konstanz, edited by Jurgen Schlaeger, 405-42I. Giessen: Hoffman.

I993 Why Novels, Why Short Stories? A Note on the Use of Genres in the Works of Albert Wendt. Commonwealth: Essays and Studies I 6 (2): 34-37.

Martin, Murray S

I984 Order, Disorder and Rage in the Islands: The Novels of V. S. 
Naipaul and Albert Wendt. Perspectives on Contemporary Literature I0:33-39.

Nazareth, Peter

I979 Coloured Man's Burden. Journal of Commonwealth Literature I4 (I): 73-86.

Nedeljkovic, Maryvonne

I98I Albert Wendt-In Between Two Cultures. Echos du Commonwealth 8:38-55.

Nightingale, Margaret

I98I Islands to Come: Albert Wendt's Fiction. New Literature Review 9:16-23.

I982 All Any Man With A Club Can Do: Albert Wendt and Witi Ihimaera. In Myth and Metaphor, edited by Robert Sellick, 53-70. Adelaide: CRNLE.

Ravell, Julia

I997 No Islands in the Sun: Anticolonialism and Identity Politics in the Novels of Albert Wendt. PhD dissertation, University of Melbourne.

Robinson, Roger

I980 Albert Wendt: An Assessment. Landfall 34 (3): 275-290. (Rp I993 in Readings in Pacific Literature, edited by Paul Sharrad, I6I-I72. Wollongong: New Literatures Research Centre, University of Wollongong.)

Schneider, Thomas

I978 Western Form for an Island Situation: Albert Wendt's Panthers. Faikava: A Tongan Literary Journal I:25-29.

Sharrad, Paul

2002 Albert Wendt and the Problem of History (Comment). Journal of Pacific History 37 (I): I09-1 I6.

2003 Albert Wendt and Pacific Literature: Circling the Void. Manchester, UK: Manchester University Press. (June)

Simms, Norman

I982 Three Steps to Maturity: The Prose Writings of Albert Wendt. Commonwealth Novel in English 2:I9I-20I.

Soaba, Russell

I983 Albert Wendt, Existential Writer. Ondobondo 3:37-4I. Subramani

I98I Oral Forms In Wendt's Fiction. Echos $d u$ Commonwealth $8: 56-67$.

I992 Wendt's Crippled Cosmos: Genesis and Form of His Novels. In 
South Pacific Literature: From Myth to Fabulation, I I7-I 50. Revised edition. Suva: Institute of Pacific Studies, University of the South Pacific.

Tiffin, Helen

I97 8 You Can't Go Home Again: The Colonial Dilemma in the Work of Albert Wendt. Meanjin 37 (I): I I9-I26.

Veramo, Joseph

I976 On Wendt-On Prejudice. UNISPAC 9 (2): 6.

Wertheim, Albert

I986 Albert Wendt and the Faa-Samoa. In Essays on Contemporary Post-Colonial Fiction, edited by Hedwig Bock and Albert Wertheim, 295-3ro. München: Max Heuber Verlag.

Wood, Briar

2000 Shamanism in Oceania. In Reading the "New" Literatures, edited by Susheila Nasta, I 29-I48. Cambridge: D S Brewer.

\section{General Studies}

Arvidson, Ken O

I973 Aspects of Writing in the South Pacific. Mana Annual of Creative Writing $\mathrm{I}: 5-8$.

I975 The Emergence of a Polynesian Literature: Hone Tuwhare, Witi Ihimaera, Albert Wendt. World Literature Written in English I4 (I): 9I-I I6. (Rp 1993 in Readings in Pacific Literature, edited by Paul Sharrad, I36-I60. Wollongong: New Literatures Research Centre, University of Wollongong.)

Blaber, Ron

I985 The Short Story of the Pacific. Span 2I:I7I-I 83 .

Brunton, Alan, Murray Edmond, and Michele Leggott, editors

2000 Big Smoke: New Zealand Poems 1960-1975. Auckland: Auckland University Press.

Corballis, Richard, and André Viola, editors

2000 Postcolonial Knitting: The Art of Jacqueline Bardolph. Palmerston North, NZ: School of English and Media Studies, Massey University; Nice, France: CRELA Université de Nice-Sophia Antipolis.

Cotter, Michael

I98I South Pacific Literature in English: Regional Solidarity in Images of Plurality. New Literature Review 9:3-6. 
Durix, Jean-Pierre

I987 The Writer Written: The Artist and Creation in New Literatures in English. Westport, Ст: Greenwood Press.

I997 Littératures Anglophones de la Caraibe, de la Nouvelle Zélande et du Pacifique Sud. In Encyclopedia Universalis, 354-355. Paris: Universalia.

Edmond, Rod

I990 South Pacific Literature: Post-Colonialism and Post-Modernism. Wasafiri I 2 (Autumn): 20-2I.

Edmond, Rod

1997 Representing the South Pacific: Colonial Discourse from Cook to Gauguin. Cambridge: Cambridge University Press.

Ellerman, Evelyn

I986 Alienation and Elemental Imagery in Camus and Wendt. MA thesis, University of Alberta.

Fairbairn-Dunlop, Peggy

I985 Samoan Writing: In Search of the Written Fagogo. Pacific Islands Communications Journal [Suva: Institute of Pacific Studies, University of the South Pacific] I4 (I): 4I-69. (Rp I993 in Readings in Pacific Literature, edited by Paul Sharrad, 20-38. Wollongong: New Literatures Research Centre, University of Wollongong.)

Griffen, Arlene

I985 The Different Drum: A Feminist Critique of Selected Works from the New Literature in English from the South Pacific. MA thesis, University of London, Institute of Education.

I988 Feminist Perspectives on Pacific Literature. Paper presented at the Pacific Writers' Conference, Commonwealth Institute, London, 27-29 Oct. Filed in the Pacific Collection, Hamilton Library, University of Hawai'i at Manoa.

Guttenbeil, 'Ofa-ki-Levuka L

I999 Knock, Knock: Is Anybody Out There? New Zealand Film: Is There Interest in Pacific Island Stories? MA thesis, Film, Television and Media Studies, University of Auckland.

Hamasaki, Richard, editor

I983 A Pacific Islands Collection: Seaweeds and Constructions 7. Honolulu: Elepaio Press.

Hereniko, Vilsoni, and Sig Schwartz

I999 Four Writers and One Critic. In Inside Out: Literature, Cul- 
tural Politics, and Identity in the New Pacific, edited by Vilsoni Hereniko and Rob Wilson, 55-64. Lanham, MD: Rowman \& Littlefield.

Huggan, Graham

I987 Blue Myth Brooding in Orchid: A Third-World Reappraisal of Island Poetics. Journal of West Indian Literature I (2): 20-28.

I994 Anthropologists and Other Frauds. Comparative Literature 46 (2): II $3-\mathrm{I} 28$.

Hughes, Shaun F D

I98I Pakeha and Maori Behind the Tattooed Face: The Emergence of a Polynesian Voice in New Zealand Fiction. Modern Fiction Studies 27 (I): I3-29.

Inkson, Gordon Kerr

I993 Renewing a Mythic Environment: A Study of Selected Novels by Vincent Eri, Patricia Grace, Witi Ihimaera, John Pule, Russell Soaba, and Albert Wendt. MA thesis, English, University of Auckland.

Ioane, Sefulu

I984 Western Influences on Samoan Poetry. Span 19: 64-77. Isernhagen, Hartwig

I984 Witi Ihimaera's Fiction from Indigenous Myth to Late Modernist City Myth. World Literature Written in English 24 ( [Summer]): I 89-I99.

I990 Fables of Interculturality: Some Comparative South Pacific Narratives. Commonwealth Essays and Studies I 2 (2): 40-5I.

James, Trevor

I986 English Literature from the Third World. Harlow: Longman. Keown, Michelle

2000 Whose Paradise? Representations of the Body in Postcolonial Pacific Writing. PhD dissertation, University of Kent.

King, Bruce

I977 Recent Commonwealth Fiction. Sewanee Review 85:I26-I34. Krauth, Nigel

I978 Contemporary Literature from the South Pacific. World Literature Written in English I7 (2 [Nov]):604-645.

Lacabanne, Sonia

1992 Les premiers romans Polynésiens: Naissance d'une littérature de langue Anglaise. Paris: Publications de la Société des Océanistes 43 . 
Manoa, Pio

I976 Singing in Their Genealogical Trees. Mana Review I (I): 6I-69.

Martin, Kristine L

I982 African and Pacific Literature: A Comparative Study. Explorations in Ethnic Studies: The Journal of the National Association for Ethnic Studies 5 (2): I-I4.

Martin, Murray S

I977 Writing Down Under: Recent Literature from Australia, New Zealand and the Pacific Islands. Choice I4 (I): I9-3I.

McLaren, John

I993 New Pacific Literatures: Culture and Environment in the Pacific. New York: Garland Publishing.

Najita, Susan Yukie

200I Pacific Literature as Local Opposition: Trauma, Magic Realism and History. PhD dissertation, University of California, Santa Barbara.

Nicole, Robert

2000 The Word, the Pen and the Pistol. Albany: State University of New York.

Ogilvie, Meredith Anne

I998 Kaina, Kaainga and Aiga: The Home Experiences of Marginalised Characters as Depicted in Four New Zealand Novels by Polynesian Authors. MA thesis, New Zealand Studies, University of Auckland.

Okonkwo, Nelson Chidi

I988 The Colonial Experience and the Third World Novel: An ExoCultural Study of the Novel in Africa, the West Indies and Polynesia. PhD dissertation, University of Auckland.

Perkins, Leialoha Apo

I989 Realism in the Myth and Fabulation of Four South Pacific Writers' Short Fiction. In Literary History, Narrative, and Culture: Selected Conference Papers, edited by Wimal Dissanayake and Steven Bradbury, I4-24. Honolulu: University of Hawai'i, College of Languages, Linguistics, and Literature.

Pillai, Raymond

I979 Prose Fiction in Fiji: A Question of Direction. Mana 4 (2): 8-IO. Ryan, Yoni

I990 A Paler Shade of White. Span 30:1 I6-I26. 
Sharrad, Paul

I989 Memory, Childhood, and Exile: Self-Representation in PostColonial Writing. Honolulu: Institute of Culture and Communication, East-West Center.

I990 Imagining the Pacific. Meanjin 49 (4): 597-606.

I994 Making Beginnings: Johnnie Frisbie and Pacific Literature. New Literary History 25 (I): I 2I-I36.

2000 Trading and Trade-Offs: Textiles and Texts in the Pacific. New Literatures Review 36:46-62.

Simms, Norman

I986 Silence and Invisibility: A Study of the Literatures of the South Pacific, Australia and New Zealand. Washington DC: Three Continents Press.

Skinner, John

1998 The South Pacific. In The Stepmother Tongue: An Introduction to New Anglophone Fiction, I 19-I30. New York: St Martin's Press.

Smith, Larry, and Sandra Tawake

I992 Culture as Reflected in Creative Literature. In Text-CultureReception: Cross-Cultural Aspects of English Studies, edited by Rüdiger Ahrens and Heinz Antor, 35 I-364. Heidelberg: Carl Winter, Universitatsverlag.

Subramani

I978 Oceania: From Oral Tradition to Literature in English. Span $6: 3 \mathrm{I}-35$.

I98I Short Fiction in the South Pacific. New Literature Review 9:7I 5 .

I982 Pacific Notes. Span I4:I4-I9.

I983 Artists in a Changing South Pacific: The Oral Poet and the Writer. In Language and Literature in Multicultural Contexts, edited by Satendra Nandan, 3I7-325. Suva, Fiji: The University of the South Pacific and the Association for Commonwealth Language and Literature Studies.

I992 South Pacific Literature: From Myth to Fabulation. Revised edition. Suva: Institute of Pacific Studies, University of the South Pacific.

Tawake, Sandra

I990 Culture and Identity in Literature of the South Pacific. World Englishes 9 (2): 205-2I3. 
I99I Multi-ethnic Literature in the Classroom: Whose Standards? World Englishes Io (3): 335-340.

2000 Transforming the Insider-Outsider Perspective: Postcolonial Fiction from the Pacific. The Contemporary Pacific I 2:I 55-I75.

Tiffin, Chris

I978a Introduction: South Pacific Images. In South Pacific Images, edited by Chris Tiffin, I-IO. St Lucia, QLD: University of Queensland.

I978b Mates, Mum, and Maui: The Theme of Maturity in Three Antipodean Novels. In Awakened Conscience: Studies in Commonwealth Literature, I27-I45. New Delhi: Stirling. (Rp 1993 in Readings in Pacific Literature, edited by Paul Sharrad, I73-I 89. Wollongong: New Literatures Research Centre, University of Wollongong.)

Va'ai, Emma Kruse

I997 Producing the Text of Culture: The Appropriation of English in Contemporary Samoa. PhD dissertation, University of New South Wales.

Va'ai, Sina Mary Theresa

I995 Literary Representations in Western Polynesia: Colonialism and Indigeneity. PhD dissertation, University of Canberra. Published 2000 Apia: National University of Samoa.

Watego, Cliff

I984 Cultural Adaptation in the South Pacific Novel. World Literature Written in English 23 (2 [Spring]): 488-496.

Webby, Elizabeth

I985 The Uses of Fiction: Some Recent Novels from the South Pacific Region. Span 21:29-37.

\section{Bibliographical Sources}

Durix, Jean-Pierre

I994 Albert Wendt. In The Routledge Encyclopedia of Post-Colonial Literature, edited by Cliff Benson, I648-1649. London: Routledge.

Goetzfridt, Nicholas J

I995 Indigenous Literatures of Oceania: A Survey of Criticism and Interpretation. Westport, Ст: Greenwood Press. 
Huggan, Graham

I996 Albert Wendt. In Contemporary Poets, edited by Thomas Riggs, I I 8I-I I 82. Sixth edition. New York: St James Press.

Rhodes, H Winston (updated by Lydna Schrecengost)

I996 Albert Wendt. In Contemporary Novelists, edited by Susan Windisch Brown, I038-I039. New York: St Martin's Press.

Simms, Norman

I99I Writers from the South Pacific: A Bio-Bibliographical Critical Encyclopedia. Washington DC: Three Continents Press.

Stringer, Jenny, editor

1996 Albert Wendt. In Oxford Companion to Twentieth-Century Literature in English, 709. Oxford: Oxford University Press.

University of Auckland Library

2002 Albert Wendt. In New Zealand Literature File. <http://www2.auckland.ac.nz/lbr/nzp/nzlit2/wendt.htm> [Based on a 1995 manuscript version developed by Kay Stead.]

Williams, Esther Wininimaori, editor

I984 Lisitala: A Bibliography of Pacific Writers. Suva: Pacific Information Centre and 4th Festival of Pacific Arts.

Williams, Mark

1996 Post-Colonial Literatures in English: Southeast Asia, New Zealand and the Pacific, I970-I992. Boston: G K Hall. 